\title{
THE WTO, SELF-DETERMINATION, AND MULTI-JURISDICTIONAL SOVEREIGNTY
}

\section{Michael Fakhri*}

In EC-Seal Products ${ }^{1}$, the World Trade Organization (WTO) Appellate Body (AB) held that the European Union (EU) Seal Regime? banning the importation of seal products could be justified under General Agreement on Tariffs and Trade (GATT) Article XX(a) ${ }^{3}$ as a measure necessary to protect public morals. It also held that the indigenous communities (IC) exception under the EU Seal Regime is inconsistent with GATT Article I:1 (Most-Favored Nation) because it discriminated against commercial fishers in Canada and Norway and was applied in a manner that favored the mostly Inuit seal hunters of Greenland, and thus ran afoul of Article XX's chapeau. Since the entire EU Seal Regime is not likely to be done away with, the most important question for Inuit communities is: how will the EU change the discriminatory aspects of the Seal Regime and IC exception? The EU faces an October deadline to pass its new legislation and this remains a very live issue. ${ }^{4}$

After the $\mathrm{AB}$ decision, animal rights activists of a certain ilk, such as People for the Ethical Treatment of Animals (PETA), claimed victory. ${ }^{5}$ It seems that the protection of animal welfare as a public moral is now a legitimate reason to restrict trade.

In Canada, many Inuit leaders were angry. ${ }^{6}$ One reason was because the ban was upheld on moral termsimplying a judgment against an important means by which Inuit communities eat and trade. Another criticism was that despite claims of some consultation by the EU, the IC exception was not really designed by or in negotiation with Inuit. ${ }^{7}$ A related problem was that the exception was useless because it was never operationalized and applied to the Canadian Inuit. Some 8 argue that the Seal Regime and IC exception violated Inuit peoples' human rights. ${ }^{9}$ Terry Audla, President of Inuit Tapiriit Kanatami ${ }^{10}$ stated after the AB decision, "[O]ur

* Associate Professor of Law at the University of Oregon School of Law.

Originally published online 25 June 2015.

1 Appellate Body Report, European Communities-Measures Prohibiting the Importation and Marketing of Seal Products, WT/DS400/AB/R, WT/DS401/AB/R (Adopted June 18, 2014) [hereinafter Appellate Body Report, EC—Seal Products].

${ }^{2}$ Regulation (EC) No 1007/2009 of the European Parliament and of the Council of 16 September 2009 on trade in seal products (Text with EEA relevance), 2009 O.J. (L 286) 36.

${ }^{3}$ General Agreement on Tariffs and Trade 1994, Apr. 15, 1994, Marrakesh Agreement Establishing the World Trade Organization, Annex 1A, 1867 UNTS 187.

${ }^{4}$ Kevin McGwin, EU seal ban: Euro parliament evenly split on seals, ARCTIC J. (May 20, 2015).

5 People for the Ethical Treatment of Animals, Victory! World Trade Organization Affirms Right to Ban Seal Fur Products, PETA/BLOG (Mar. 25, 2014).

${ }^{6}$ Inuit Furious as World Trade Organization Upholds European Union Seal Ban, Indian COUNTRY TODAY MEDIA NETWORK (May 23, 2014).

7 Inuit Tapiriit Kanatami, Media release, Inuit Decry WTO Appellate Decision to Uphold Discriminatory, Flawed Seal Ban (May 22, 2014).

${ }^{8}$ Kamrul Hossain, The EU ban of the import of seal products and the WTO regulations: neglected buman rights of the Arctic indigenous peoples?, 49 POLAR RECORD 154 (2013).

${ }^{9}$ Dorothee Cambou, The Impact of the Ban on Seal Products on the Rights of Indigenous Peoples: A European Issue, 5 Y.B. POLAR L. ONLINE 389 (2013).

${ }^{10}$ Inuit Tapiriit Kanatami. 
position from the start has been a rejection of the seal ban regulation as a whole, including all that is contained in it, including the Inuit exemption." 11

Seeing the case in strictly adversarial terms - like Canada and Norway v. EU or Animal rights activists v. Inuit peoples $^{12}$ - fails to capture the full range of issues at play in this case. Nor is this case solely a matter of trying to balance economic interests, public morals, and animal welfare. ${ }^{13}$ One clue that there is more at stake arises from how the EU argued before the AB. In this case, the focus of the EU Seal Regime was strictly in terms of seal suffering (seal conservation was not in question). Regardless, the EU put most of its energy towards framing its GATT general exception arguments regarding seal welfare in terms of public morals (Art. XX(a)) and spent little effort framing things in terms of actual seal health (Art. XX(b)). Since public morals encompass a wide range of policy matters, this suggests that the EU acted upon the issue more in terms of exercising its political authority and ensuring it maintained its ability to address citizens' demands and not animal rights.

With a focus on Canada, I suggest that the dispute is about more than just the trade in seal products. This case brings into stark relief questions of self-determination of Arctic indigenous peoples and multi-jurisdictional sovereignty over the Arctic. I also propose how Inuit leaders may interpret this decision as a legal victory that grants them more political leverage in future negotiations. Despite the initial setbacks, this approach may allow them to have more control over the long-term socioeconomic repercussions of this case.

What Is at Stake?

In Canada, the seal-hunt industry provided part-time employment for up to six thousand people, mostly in rural Atlantic Canada. ${ }^{14}$ The annual value of the hunt was about thirty-five to forty million Canadian dollar (CAD) and could represent about 25-35 percent of sealers' total annual income. Before the EU ban, Inuit incomes from seal pelts could reach up to one million CAD annually.

Only approximately 5 percent of seal hunts in Canada (and Norway) would fall under the IC exception. ${ }^{15} \mathrm{Up}$ until now, Canada has been representing the interests of indigenous and non-indigenous seal hunters as a single group; it argued before the $\mathrm{AB}$ that there should not be a distinction between different seal hunters.

Canada and Norway argued before the AB that the IC exception has unfairly granted Greenlandic hunters, who are almost entirely indigenous Inuit, a substantial increase in market share in the EU. In Greenland, virtually all hunts fall under the IC exception. ${ }^{16}$

The IC exception on its own did not provide Canadian Inuit peoples much actual benefit because the wording of the legislation lacked clarity and proper implementation procedures. All it did was empower the European Commission to "define the conditions for the placing on the market of seal products which result from hunts traditionally conducted by Inuit and other indigenous communities and contribute to their subsistence." It is therefore not surprising that Greenland, with its predominantly Inuit population and its constitutional ties with Denmark, an EU member state, was proactive when the Seal Regime was enacted and negotiated with the EU

11 Inuit Tapiriit Katanami, supra note 7.

12 Terry Audla, The Only People Making Money Off the Seal Hunt Are Anti-Sealing Campaigners, Huffington Post CanADA Blog (Apr. $28,2014)$.

13 Robert Howse et al., Sealing the Deal: The WTO's Appellate Body Report in EC-Seal Products, 18 ASIL INSIGHTS Issue 12 (June 04 , 2014).

${ }^{14}$ Government of Canada, Seals.

15 Panel Report, European Communities-Measures Prohibiting the Importation and Marketing of Seal Products, WT/DS400/AB/R, WT/DS401/AB/R (Adopted June 18, 2014), para. 7.597 [hereinafter Panel Report, EC—Seal Products].

${ }^{16} \underline{I d}$. 
to establish a system that implemented the IC exception. ${ }^{17}$ Canada instead focused its efforts on challenging the EU Seal Regime as a whole and did nothing to work with the EU to implement the IC exception.

Since the AB decision upholds the Seal Regime but forces the EU to make its IC exception WTO compliant, the Government of Canada and the EU, as declared in a Joint Statement, are now working out the details of how to make the IC exception actually benefit indigenous communities in Canada. ${ }^{18}$ The Government of Nunavut and some Inuit leaders welcomed this initiative. ${ }^{19}$ Similarly, after the $\mathrm{AB}$ decision, the Premiers of Nunavut and Greenland have also issued a Joint Statement and expressed a commitment to coordinate efforts and work through the EU seal ban in order to improve the lives of Inuit peoples. ${ }^{20}$

The EU's wording, interpretation, and implementation of the new IC exception will determine whether it will benefit indigenous communities. The now-old EU Seal Regime only provided an exception for indigenous seal hunts on three conditions: that the hunt contributes to the subsistence of the community, that the hunt is part of the community's tradition, and that the products are at least partly used and consumed in a traditional way.

If this type of wording remains, the scale of indigenous seal hunting, trading, and economic development will be determined by how the terms — subsistence and tradition—are understood and defined. Within this framework, future debates will be over what counts as or exceeds "subsistence." 21 Ecuador probably anticipated this point when it made its oral statement before the $\mathrm{AB}$ and supported the Panel's definition of subsistence to include income-generating activities necessary to support traditional forms of life for indigenous communities. This implied that commerce is a central component of indigenous hunts, and not a secondary result of trading what is left over after local use. The other danger is that indigenous traditions may be interpreted by the EU as a static, anthropological practice (or even worse as a caricature) rather than as a dynamic, modern relationship between past and present.

Regardless of the new wording, the fundamental problem that remains in EU-indigenous relations is that the WTO legitimized the EU, instead of indigenous communities themselves, as the body that gets to define what constitutes legitimate hunting.

While the socioeconomic benefits remain unclear, this decision may be a political victory for indigenous communities in broader international legal terms. Canada (and Norway) used various techniques during the dispute to argue against privileging the category of "indigenous." For the Government of Canada, this was partially an effort to protect the economic interests of the nonindigenous rural communities in Atlantic Canada that that make up 95 percent of Canadian seal hunts. It was also part of the Government of Canada's longstanding campaign to resist recognizing explicit indigenous rights in international law.

${ }_{17}$ European Commission, Commission Decision recognising the Greenland Department of Fisheries, Hunting and Agriculture (APNN) for the purposes of Article 6 of Commission Regulation (EU) No 737/2010 of 10 August 2010 laying down detailed rules for the implementation of Regulation (EC) No 1007/2009 of the European Parliament and of the Council on trade in seal products, Apr. 25, 2013, C(2013) 2277 final.

${ }^{18}$ European Commission, Annex, Joint Statement by Canada and the European Union on Access to the European Union of Seal Products from Indigenous Communities of Canada to the Commission Decision on the Joint Statement by Canada and the European Union on Access to the European Union of Seal Products from Indigenous Communities of Canada, Aug. 18, 2014, C(2014) 5881 final Annex 1.

${ }^{19}$ Government of Canada, Foreign Affairs, Trade and Development of Canada, News release, Canada Pursues Expanded Access and Opportunities in European Markets for Indigenous Sealers (Oct. 10, 2014,).

${ }^{20}$ Joint Statement of Aleqa Hammond, Premier of Greenland, and Peter Taptuna, Premier of Nunavut Nuuk (July 2, 2014).

21 Appellate Body Report, EC-Seal Products, supra note 1, at para. 5.324. 


\section{Who Is Indigenous in International Law?}

With a long history of oppression and displacement, the stakes are high for indigenous communities demanding international legal recognition. International law avoids providing too precise a definition of who constitutes indigenous peoples. ${ }^{22}$ "Indigenous peoples" is a category that is both dependent on history but ever changing in the present. The concept is part of a continuous process of lived experiences. It is defined through a particular social and institutional context, and by the process of certain claims and conflicts. As such, there are a plethora of legal instruments that define indigenous peoples in varying degrees of specificity and in multiple ways. ${ }^{23}$ As an international legal concept, it has the power to mobilize marginalized groups; any strict definition will inevitably be controversial for being overinconclusive to some and underinclusive to others.

The UN Declaration on the Rights of Indigenous Peoples passed by the General Assembly in 2007 was a significant moment for advancing the legal power that indigenous communities may wield. ${ }^{24}$ The UN Declaration was adopted on September 13, 2007, when 143 countries voted in favor. Australia, Canada, New Zealand, and the United States — which are all settler colonies with varying degrees of tense indigenous relations_ — voted against. Since the original vote, these four countries have moved to endorse the Declaration but still argue that it is not legally binding.

The UN Declaration played an important role in the EU Seal Ban dispute. The IC exception itself explicitly relies on the UN Declaration (Recital 14 of the Basic Regulation), and, during the dispute, the EU also referenced the ILO Indigenous and Tribal Peoples Convention 25 . Canada argued before the AB that the Panel committed a legal error "by relying on international instruments extraneous to the case" and that these instruments do not require the EU to protect the rights and interests of indigenous communities. ${ }^{26}$

The Panel was careful in framing the non-WTO instruments as matters of fact of which the EU relied on as its own legal obligations and not as obligations to all WTO Members. ${ }^{27}$ Nonetheless, the Panel took note and to some degree relied upon an expert report that referenced several international legal instruments (the UN Declaration, the ILO Convention, and the Charter of the Inuit Circumpolar Council) to frame hunters' status as belonging to an Inuit or indigenous community as one based on self-determination.

The AB stepped around the perennial debate regarding what non-WTO sources may be brought into a WTO dispute and did not address it in its decision. But, it recognized the legitimacy of the IC exception of the EU Seal Regime. In a sense, the WTO affirms indigenous communities as an international legal concept, and puts into effect the EU expression of its international legal obligations in the context of international indigenous rights and seal hunting in the Arctic. For indigenous leaders, this may strengthen their position to argue that when Canada and the EU operationalize the IC exception, they are implicitly recognizing the binding nature of the UN Declaration (even as Canada denies such force).

What remains to be seen is how this decision will affect seal hunting in other parts of the world. It may also resonate across indigenous hunting rights in more global contexts. For better or for worse, this case is a reminder that indigenous communities in the Arctic need to continue to find ways to actively engage with, respond to, or resist the WTO lest they are treated as mere objects of other actors' interests and policies. At

${ }^{22}$ Benedict Kingsbury, "Indigenous Peoples" in International Law: A Constructivist Approach to the Asian Controversy, in THE CONCEPT OF INDigenOus PEOPLES IN ASIA 103 (Christian Erni ed., 2008).

${ }^{23}$ Christopher C. Dykes, UPDATE: Research Guide on Indigenous Peoples in International Law (July/Aug. 2012).

${ }^{24}$ United Nations Declaration on the Rights of Indigenous Peoples, G.A. Res. 61/295 (Oct. 2, 2007).

${ }^{25}$ Convention concerning Indigenous and Tribal Peoples in Independent Countries (ILO No. 169), June 27 1989, 28 ILM 1382 (1989).

26 Appellate Body Report, EC-Seal Products, supra note 1, at para. 2.4.

${ }_{27}$ Panel Report, EC-Seal Products, supra note 14, at para. 7.295. 
worst, WTO law will impose conditions to their detriment. At best, WTO law may be part of the international legal repertoire that indigenous communities should consider, along with international human rights law, when determining how to deploy legal instruments to best serve their aspirations and interests.

\section{Self-determination and Sovereignty}

One of the UN Declaration's main purposes and effects is reaffirming the indigenous right to self-determination. But self-determination is a notoriously tricky concept. Historically, former colonial subjects have debated amongst themselves over how to configure self-determination in relation to sovereignty as a tactical question. ${ }^{28}$ One way to understand self-determination is as the power to constitute a community as a political and legal actor. It is also the power to express one's interests through existing institutions. Sovereignty is more about control over territory, and everything and everyone within the territory. It is also the power to create rules and institutions.

Self-determination may be aligned with the concept of sovereignty by establishing a sovereign state. Or, selfdetermination is expressed within a sovereign state by carving out zones of varying degrees of autonomy through mechanisms such as indigenous rights, indigenous "reservations," or sub-federal governments. Sometimes self-determination is expressed across several sovereign borders. This arises when an indigenous group represents the interests of its members who live in different states. Self-determination can also be deployed against a sovereign power. ${ }^{29}$ Add to the mix the politics of different groups competing over who rightfully speaks for a people..$^{30}$ The UN Declaration is very careful in preserving existing state sovereignty and ensuring that the instrument cannot be used "as authorizing or encouraging any action which would dismember or impair, totally or in part, the territorial integrity or political unity of sovereign and independent States" (Art. 46).

As evidenced in the list of international legal instruments expressing indigenous rights, ${ }^{31}$ self-determination is enacted through a variety of institutional authorities. By implicitly recognizing indigenous rights, the $A B$ Report not only reflects and strengthens indigenous rights in international law in general, but it also highlights how the WTO is one institution through which indigenous self-determination is constituted through existing sovereign boundaries. In the future, international trade law and domestic commercial law will likely continue to be fields through which people will argue over indigenous rights.

It remains to be seen whether the new IC exception will make seal hunting more lucrative for Inuit in Canada. Part of the Inuit frustration is how Canada and the EU have until now excluded them from most processes of meaningful decision-making. ${ }^{32}$ What is clear, however, is that once the new exception is implemented and made WTO compliant, Inuit hunters will be the only ones allowed to export to the EU. A significant part of selfdetermination is a people's right to freely choose their own political and economic systems, and their own way of life. Inuit communities claim seal hunting as a central aspect of their life; this exclusive market access reingrains the importance of hunting in Inuit life and re-affirms their right to self-determination.

28 Robert Knox, Strategy and Tactics, 21 FinNiSH Y.B. INT’L L. 193 (2012).

${ }^{29}$ IN THE MATTER OF Section 53 of the Supreme Court Act, R.S.C., 1985, c. S-26; AND IN THE MATTER OF a Reference by the Governor in Council concerning certain questions relating to the secession of Quebec from Canada, as set out in Order in Council P.C. 1996-1497, [1998] 2 S.C.R. 217 (Can.).

${ }^{30}$ Mohawk Nation Council of Chiefs of the Haudenosaunee Six Nations Confederacy, About the Mohawk Nation Council of Chiefs.

31 Dykes, supra note 23.

32 Derek Inman et al., “We Will Remain Idle No More”: The Shortcomings of Canada's 'Duty to Consult' Indigenous People, 5 GOETTINGEN J. INT’L L. 251 (2013). 
Moreover, given that most subsistence hunters in the Arctic are Inuit, Inuit now have a mix of a monopoly over Arctic subsistence hunting (in fact) and sales to the EU (in law). They can claim that this mix enacts and strengthens their right to self-determination in international law. More specifically, Inuit leaders have more bargaining power to argue that they must have direct involvement in the design and implementation of the new EU legislation.

The AB had to determine the EU Seal Regime's objective as part of its Article XX-exception analysis. The disputants agreed that the main purpose of the EU legislation was the protection of seal welfare as a moral concern. The question arose as to the scope of moral interests. Norway unsuccessfully argued that the EU legislation made exceptions for particular interests - indigenous, marine resource management, and travelersand that these were separate from the moral purpose. The $A B$ treated the exceptions as part of the moral concerns involved. ${ }^{33}$ In effect, the $\mathrm{AB}$ affirmed that any debate in the EU over seal welfare had to address indigenous interests. So, while EU legislation framed indigenous rights as a legal exception and animal rights activists argued that Inuit hunting practices were immoral, the $\mathrm{AB}$ ensured that indigenous peoples' interests were considered as a principal legal and moral concern in all EU seal-hunting laws.

Inuit communities have an opportunity to get out ahead and argue that the decision recognizes not only their rights and interests in seal hunting, but their rights to self-determination more broadly. There may be opportunities not only at the WTO (or the European Court of Justice ${ }^{34}$ ), but also in other jurisdictions and with regard to other markets to use the $\mathrm{AB}$ decision and assert their interests.

\section{Arctic Space and Multijurisdictional Sovereignty}

If self-determination is articulated through hunting practices, sovereignty is articulated through hunting rules. Whoever makes the rules of seal hunting is in effect exercising some sovereign power in the Arctic. Seal hunting might be seen as part of a much broader jockeying for control and authority in the Arctic.

The AB's decision implicates a wider mesh of overlapping sovereign power in the Arctic. Here's a rough, incomplete political and institutional map of Arctic sovereignty:

The Government of Nunavut is a semi-autonomous body governing a mostly Inuit community. Because Nunavut is a Canadian territory, it is created through federal law (unlike provinces which are created by the Canadian Constitution). This means it theoretically has a more direct relationship with the Federal government than the provinces. Broadly speaking, the Government of Canada's relationship with the diverse group of indigenous communities has been fraught. For example, recently, the UN Rapporteur on the Right to Food found that the Government of Canada has neglected the socioeconomic well-being of indigenous communities and has diminished indigenous control over land and natural resources. ${ }^{35}$

Greenland is an autonomous country within the Kingdom of Denmark. Unlike Denmark, Greenland is not a member of the EU. Nor is it a party to the pan-European Schengen visa agreement. But to enter Greenland, citizens of Nordic countries need only a valid identification card—suggesting that the Nordic Council 36 is one forum for negotiating Arctic sovereignty. While Norway is not an EU member, it remains closely economically integrated through its membership in the European Economic Area. In North America, the Pacific NorthWest

\footnotetext{
33 Appellate Body Report, EC-Seal products, supra note 1, at paras. 5.147, 5.161.

${ }^{44}$ Case C-583/11 P, Inuit Tapiriit Kanatami and Others v. Parliament and Council, ECLI:EU:C:2013:625 (2013).

${ }^{35}$ UNHRC, Report of the Special Rapporteur on the right to food, Olivier De Schutter, UN Doc. A/HRC/22/50/Add.1 (2012).

${ }^{36}$ Norden.
} 
Economic Region is increasingly becoming an important forum for business and political leaders to align their Arctic interests. ${ }^{37}$

The Inuit Circumpolar Council is a multinational nongovernmental organization representing Inuit/Yupik peoples living in Alaska ${ }^{38}$ (United States), Canada, ${ }^{39}$ Greenland, ${ }^{40}$ and Chukotka (Russia) ${ }^{41}$.

The Arctic Council ${ }^{42}$ is the intergovernmental forum that addresses issues faced by the Arctic governments and indigenous peoples. It has eight member countries: Canada, Denmark (including Greenland and the Faroe Islands), Finland, Iceland, Norway, Russia, Sweden, and the United States. Six Arctic indigenous communities have Permanent Participant status. A number of countries have Permanent Observer status. The council's original purpose may have been to primarily focus on environmental protection and sustainable development issues, but it has become the principal forum for negotiating and constituting Arctic sovereignty.

The EU's ban on the seal hunt is one way through which it exercises sovereign power in the Arctic. The EU, however, has bigger plans than just regulating seal hunts. It has been trying to become a Permanent Observer of the Arctic Council as a means to increase its role in polar geopolitics. Until now, its permanent status has been vetoed by Canada as an explicit response to the seal hunt dispute. ${ }^{43}$ Some argue that the Canada-EU Joint Statement changes Canada's position in the Arctic Council and may open avenues for EU permanent status. ${ }^{44}$ But demonstrating the complexity of both the seal trade and polar politics, Greenland is threatening to veto the EU's Arctic Council membership now that its seal products' privileged access to the EU market is threatened after the $\mathrm{AB}$ decision. ${ }^{45}$

\section{Shifting Interests}

The biggest losers ${ }^{46}$ in this case are the nonindigenous communities that depend on seal hunting in Atlantic Canada - the so-called commercial hunters. ${ }^{47}$ They were done in by both the WTO and EU. This is tragic since these communities have been on a sharp socioeconomic decline since the fisheries collapse in the 1990s. Up until now, the Government of Canada was primarily representing their interests in the WTO dispute. However, it looks like an EU Seal Regime with an IC exception is here to stay in some form. So, only the Government of Canada and respective provincial governments will be able to provide these communities any immediate relief.

That also means that the Government of Canada is likely to shift its energies and put more emphasis on representing Inuit seal hunting interests in international trade and other international forums-mostly to enhance its Arctic sovereignty claims. Since the Government of Nunavut is a key player in how the Government of Canada exercises Arctic sovereignty, this AB decision grants the Government of Nunavut and Inuit leaders more leverage when negotiating with the Government of Canada regarding support and resources for Inuit

\footnotetext{
${ }^{37}$ The Pacific NorthWest Economic Region Arctic Caucus.

${ }^{38}$ Inuit Circumpolar Council-Alaska.

${ }^{39}$ Inuit Circumpolar Council Canada.

${ }^{40}$ Inuit Circumpolar Council Greenland.

${ }^{41}$ Inuit Circumpolar Council Russia.

42 Arctic Council.

${ }^{43}$ Canada against EU entry to Arctic Council because of seal trade ban, CANAdian BroadCASTING Corporation News (Apr. 29, 2009).

${ }^{44}$ International Centre for Trade and Sustainable Development, Implementation moves abead on WTO seal ban dispute (Sep. 15, 2014).

${ }^{45}$ Kevin McGwin, EU seal ban: A seal of disapproval, THE ArCTIC JOURNAL (Feb. 18, 2015).

46 Tom Ayers Cape Breton Bureau, Seal bunt off Nova Scotia dormant as pelt market disappears, HerAld News (Mar. 31, 2015).

${ }^{47}$ Nina Lex, EU seal ban seen as threat to Newfoundland villages, REUTERS (Aug. 7, 2009).
} 
peoples. ${ }^{48}$ And so, this may be an opportunity for Inuit communities to get more from the Government of Canada in the short term and enhance their position under international law in the long term.

48 Terry Audla, Terry Audla on Idle No More: The view from the (far, far) North, NATIONAL Post (Jan. 29, 2013). 